\title{
The pioneers of mensural music printing in German-speaking lands: networks and type repertoria
}

\author{
Andrea Lindmayr-Brandl
}

Soon after Ottaviano Petrucci started producing polyphonic music books by using a multiple-impression technique, some German printers attempted to seize a share of the same market. Music printing was still an exciting new enterprise with a yet uncertain expectation of success, and only a handful of printers took the risk of producing fonts for mensural notation. They began this new line of their business in the awareness that this product required a higher degree of technical effort and workers knowledgeable about music. In this chapter I will introduce these men, discuss the kinds of repertoire and sources they published, and describe and compare their music fonts. As a contribution to cultural material studies, I offer a type repertory of early German music fonts for printing mensural notation through multiple impression, as Mary Kay Duggan did for music incunabula and Donald W. Krummel for the single-impression technique in the same area. ${ }^{1}$

\section{Background and overview}

When German printers first used a multiple-impression process to print mensural music in 1507, the technique had already been known in German-speaking territories for decades. Starting with the Gutenberg workshop, printers produced many books with pages set in at least two colours. At this early stage, this printing practice concerned mainly liturgical books, such as missals, breviaries, psalters or agendas. Colour was used for initials, for important words on the title page and in continuous text, and for long instructional sections (rubrics), to embellish and to structure the book. Some printers even specialised in printing illustrations in many colours. ${ }^{2}$ The challenge for the pressmen was to place the paper on the tympan in such a way that the second impression in the other colour was perfectly aligned ('in register') with the first. The difficulty of this process is indicated by the survival of misprinted pages that were not discarded but incorporated into a book. ${ }^{3} \mathrm{It}$ was only a small step to printing chant melodies in double-impression technique: instead of letter types, notational shapes were cast and composed like words, not in a single line but within a two-dimensional space. Black text and black notes were printed together, and in a second impression the staff in red ink and red text and initials were added (or the other way round). This was no different from the regular process for printing liturgical books, but required extra types, a careful typesetter and a knowledgeable editor or proofreader. ${ }^{4}$ In rare cases the name of the editor is indicated in the colophon. ${ }^{5}$

Nevertheless, it took about twenty years after the invention of letter-printing before the appearance of the first edition with printed chant notation in double impression, the socalled 'Constance Gradual'. ${ }^{6}$ It took another thirty years until this technique was applied to polyphonic music in mensural notation. Before this time, we know of seventy-eight 


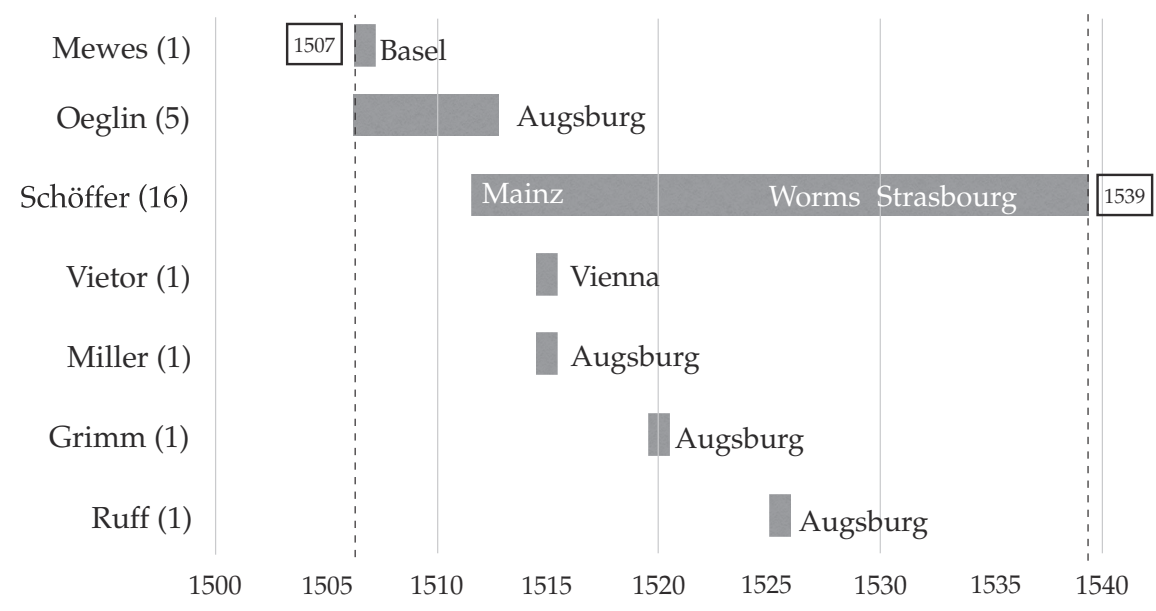

Figure 1.1 Printers and printing production through time.

liturgical books printed in several cities within the German-speaking lands. Leading the list is Augsburg (26 editions, all by Erhard Ratdolt), followed by Nuremberg (10 editions), Basel (9 editions), Würzburg (6), Strasbourg and Bamberg (4), Leipzig and Speyer (3), Vienna and Lübeck (2). ${ }^{7}$ It is remarkable that Mainz, the cradle of printing, is not represented in this list. ${ }^{8}$ Obviously music printing was not part of the agenda of the workshops of this town.

Although one might expect that the development of polyphonic music printing should have started in workshops experienced in printing chant notation, this was not the case. Figure 1.1 provides an overview of all seven printers who pioneered this new business, arranged chronologically by the date of their first polyphonic edition, from Mewes to Ruff. Their output within the period 1507-1539 is indicated on a horizontal time axis, with the places of printing added on the right or within the bar. Also here Augsburg is dominant, but Nuremberg does not appear at all. Mainz, however, is very present.

The visualisation of the production exemplifies that two groups of printers can be distinguished: 'one-shot printers', and those who were active over a longer period of time, namely, Erhard Oeglin, who printed five known editions between 1507 and about 1512/1513; and Peter Schöffer the Younger, who produced sixteen known editions between 1512 and 1539. ${ }^{9}$ Within thirty-three years, only twenty-six editions with mensural notation were produced in German-speaking lands, or - perhaps better - have survived from this area. ${ }^{10}$ We must remember that further editions have disappeared without trace. ${ }^{11}$ But even if we assume a $50 \%$ rate of loss, the number of musical editions is still quite small for this time span. However, these books cover a broad range of repertoire: masses, motets, Magnificat settings, songs, hymns and polyphonic ode settings, in many cases arranged in partbooks, but also in choirbook layout, some humanist books, a pamphlet and two broadsheets (see Appendix 1.2).

\section{The individual printers}

\section{A start in Basel: Gregor Mewes}

One of the first men who experimented with techniques to print polyphonic music was Gregor Mewes, a printer from northern Germany who worked in Basel, from 1504 at the latest, and who died in late 1516 or after. ${ }^{12}$ At this time, Basel was a centre of book 
production, and workshops here had been printing chant in double impression since the early 1480s. ${ }^{13}$ As Birgit Lodes has shown, Mewes was an apprentice in the workshop of Jacob Wolff von Pforzheim, who was also active in music printing. Until then, Wolff had only printed music from woodcuts. ${ }^{14}$ Mewes might have profited from the fact that the networks between the Basel printers were aware of experiments with the technical challenges of production. Nevertheless, Mewes must have been an extraordinary personality, who put everything into exploring a new field and taking great financial risks when he published his only known music book in the first half of the year 1507. Mewes' output was a set of four partbooks containing four masses by Jacob Obrecht. The books reveal little about their circumstances of origin, since they lack a colophon and a dedication.

Figure 1.2 shows one page from this book, displaying its neat music fonts, including ligatures and careful layout. In the lowest staff of the example, Mewes even extended the stem of the longa with breve rests so that it would match the length of the other note stems. A letter to the readers informs us that Mewes has worked on this exceptional work 'summa lucubratione', during the night (if we take his words literally). This common expression from Cicero means that the reader cannot blame the author (or, in this case, the printer) if the book is not perfect, since it is merely the product of one's leisure hours, however diligent. ${ }^{15}$ Also the fact that the author of the letter mentions the printer not by his regular name - Mewes is not a surname but a northern German nickname for Bartholomäus or Matthäus (Mäus $\rightarrow$ Mewes) - indicates that it was a personal enterprise. ${ }^{16} \mathrm{~A}$ few years later, Mewes would have his own print shop, where he printed under his proper name Gregorius Bartholomäus. Birgit Lodes, who deduced the identity of Mewes and the date of the publication, has demonstrated that he had had no models for this experiment, neither Petrucci nor any other sources. ${ }^{17}$

Furthermore, neither he nor any other printer in Basel produced any known edition of polyphony. It looks to me like a masterstroke, a personal satisfaction for the printer who

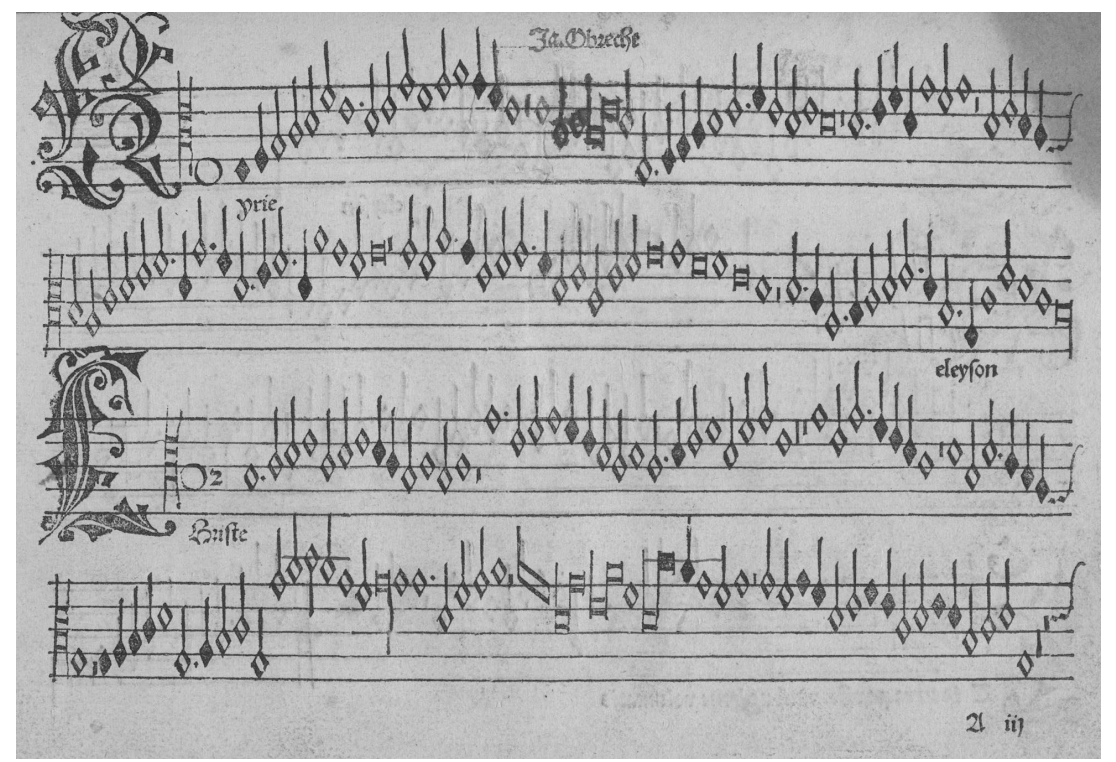

Figure 1.2 Gregor Mewes. Concentus harmonici quattuor missarum (Basel, [1507]), vdm 630, Tenor partbook.

Source: Basel, Universitätsbibliothek, KK III 23a, fol. A3 . 
was able to succeed technically. But it also could have been a financial failure, since we do not know if there was a ready market for a collection of demanding polyphonic music in the area, and Mewes might have stopped printing music for this reason. In any case, it had no consequences for the development of a new line of business in the city.

\section{Another start in Augsburg: Erhard Oeglin}

Mewes might have been the first to print polyphonic music in German-speaking countries, but Erhard Oeglin (c. 1470-1520) claimed the credit. He, too, learnt his craft in Basel, but then moved to Augsburg, where he established a small printing workshop on his own in 1502. This imperial city was another centre of printing. Although it was not the seat of a university, it had an active intellectual and cultural life, based on the clergy and mercantile and banking families, prominently the Fuggers and Welsers, who benefited from the frequent residences and the ambitious enterprises of Emperor Maximilian I. The Augsburg printers focussed on books with woodcut illustrations and on books in the vernacular. Oeglin's use of Hebrew type indicates his readiness to undertake capital expenditure and experimentation. ${ }^{18}$

Oeglin's first musical edition, the Melopoiae, was a selection of homophonic settings of odes, mainly by Horace, set to music by Petrus Tritonius. ${ }^{19}$ It appeared in the same year as Mewes' mass collection, 1507. The circumstances of its origin are much clearer. The edition emerged from the humanist circle around the poet Konrad Celtis and the Augsburg town clerk Conrad Peutinger, who was also a counsellor to Maximilian. This sodalitas litteraria, as such associations were called, supported the printers mainly by supplying reliable texts, producing paratexts - poems and letters - and correcting the proofs. The fact that the publication of the Melopoiae was funded by Johannes Rynmann, a successful publisher and bookseller based in Augsburg, should remind us that printing was already a business with frequently shared responsibilities, even if this was not explicitly mentioned. ${ }^{20}$ In this case the colophon pays tribute to both men: to Oeglin for his practical ingenuity and diligence, and to Rynmann for his funding. In the passage following the colophon, Oeglin is also praised as the first German who used metal types for printing (polyphonic) music:

Impressum Augusta uindelicorum ingenio \& industria Erhardi Oglin

Expensis Ioannis Riman alias de canna et Oringen

Ad Erhardum Oglin impressorem

Inter germanos nostros fuit Oglin Erhardus

Qui primus intidas [sc. nitidas] pressit in æris notas

Primus et hic lyricas expressit carmine musas

Quatuor et docuit uocibus ære cani ${ }^{21}$

[colophon:] Printed at Augsburg through the genius and industry of Erhard Oeglin, with the funding of Johannes Rynmann, of Cannstatt and Öhringen.

[poem:] To the printer Erhard Oeglin: Among us Germans it was Erhard Oeglin who first pressed shimmering notes in metal. He was also the first to print lyric poems in song and to teach us to sing in four voices from a printed book.

The layout of the book is adopted from a sacred choirbook, but in a small folio format, with all four parts arranged on one opening (see Figure 1.3, first opening of the music section). Compared with the regular sacred repertoire that is usually allocated on the two pages, the ode settings are quite short. As a consequence, the parts of two or three settings are placed 

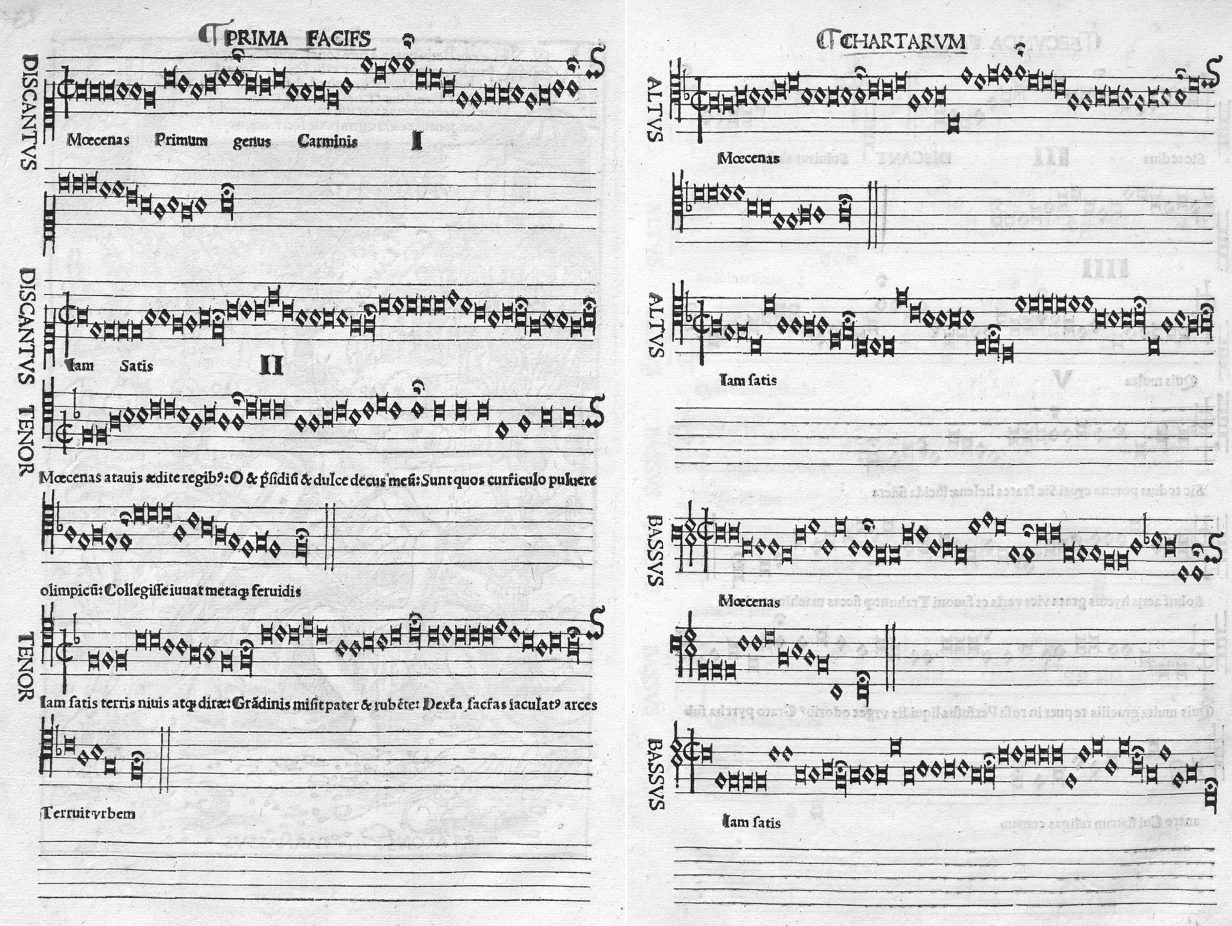

Figure 1.3 Erhard Oeglin. Melopoiae sive harmoniae tetracenticae (Augsburg, 1507), vdm 55.

Source: Munich, Bayerische Staatsbibliothek, Rar. 291, fols. A2 $-3^{\mathrm{r}}$.

underneath each other so that the impression is a bit confusing. One might think that one was reading a composition for double choir with two (or three) parts for each voice. ${ }^{22}$

Presumably as a reaction against such an unsatisfactory mise-en-page, Oeglin changed the format when he published a second and corrected edition in the same year. Here he used quarto format and placed one setting on each opening, which made more sense to users. When he printed two collections with German songs in sexto and octavo five years later, he reduced the size of the book again. (The repertoire of the two song books in vernacular language fit well into the general Augsburg printing programme.) The print in the small pocket size is in octavo oblong format and splits the voices into individual partbooks (see Figure 1.4, p. 24). As a consequence of this shrinking of format, the music notation, which was originally designed for a book in folio format, appears rather oversized for a songbook, especially for the book printed in oblong octavo format, in which the pages are quite tightly packed.

Besides the Melopoiae, Harmonie and the two songbooks, the only other surviving edition from Oeglin's press is a broadsheet with a hymn melody. Oeglin might have planned to print even more polyphonic books to make the most of the specially produced font, but he soon had problems with the court: in 1513 he lost his title as an imperial printer when he was banished from the city. The reasons are unclear, but judging from the unusually harsh sentence, we can speculate that he might have misused the emperor's heraldic arms to advertise his products. It was presumably through Peutinger's intervention that Oeglin was soon allowed to return to Augsburg, but he never obtained another imperial order. Oeglin was again cautioned for printing invective works in 1520 and died shortly afterwards. The 


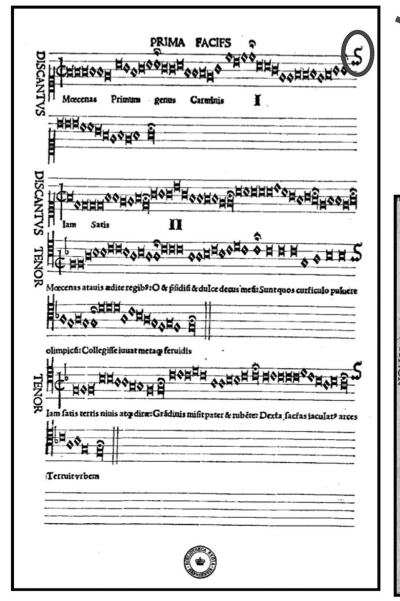

$\operatorname{vdm} 55\left(\right.$ choirbook, $\left.2^{\circ}\right)$

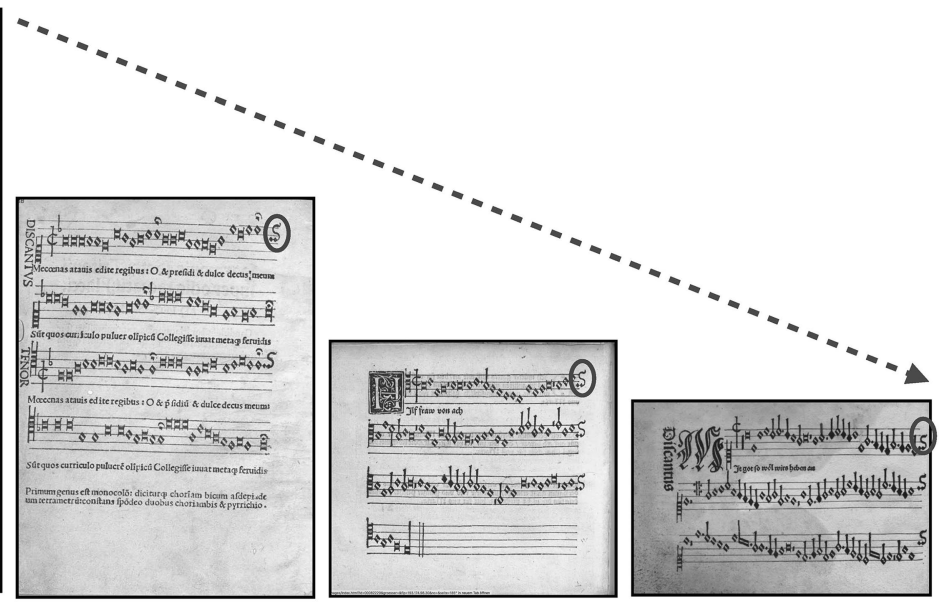

$\operatorname{vdm} 108\left(\right.$ choirbook, $\left.4^{\circ}\right)$ vdm $11\left(\right.$ partbook, $\left.6^{\circ}\right) \quad$ vdm $14\left(\right.$ partbook, $\left.8^{\circ}\right)$

Figure 1.4 Erhard Oeglin (Augsburg): format shrinking.

letter types were passed on to Philipp Ulhart the Elder, another Augsburg printer, but the music types disappeared..$^{23}$

\section{More Augsburg printers: Johann Miller, Grimm and Wyrsung, Simprecht Ruff}

In contrast to Mewes, Oeglin left a legacy as music printer in the city. Three other printers followed in his footsteps, all closely affiliated with the humanist network of Augsburg. Johann Miller (c. 1475-1528), who came from a rich patrician family, studied Greek and Latin at Ingolstadt and inherited a fortune from his father, may have collaborated with Oeglin for a while. His only musical edition in double impression is the humanistic treatise Quadratum sapientiae by Johannes Foeniseca, published in 1515. Besides the medieval 'seven liberal arts' (septem artes liberales), it contains additional chapters, covering geography, medicine, metaphysics and an introduction to Hebrew grammar. Here Foeniseca indicates the pronunciation and prosody of the language with breves and semibreves on two staff lines. Since Hebrew reads from right to left, the music also runs in this direction; the clef is located on the right end of the system, but is not mirrored. If one did that it would no longer resemble the letter $\mathrm{F}$ and thus lose its meaning (see Figure 1.5). Although the notation is quite simple, it involves a double-impression technique with a reduced number of types (only breves, semibreves, f-clefs and staff lines in blocks $18 \mathrm{~mm}$ long). That the music notes were not identical with Oeglin's font becomes explicit when measuring them: Miller's breves are $3.5 \mathrm{~mm}$ high, Oeglin's breves $5 \mathrm{~mm}$; furthermore, the clef is different (see Appendix 1.1). It seems that the music fonts were cast specifically for this edition, since they were not used in another edition which Miller printed the following year. The treatise Musica rudimenta by Nicolaus Faber (vdm 448) contains mensural music notation only on the title page. The short monophonic ode setting could have easily been printed from the types used for Foeniseca's book by adding longs and fermatas. However, the music is cut in wood, while the text underlay is set in type. The page also contains an illustrative title woodcut. One might wonder why Miller, who was also active as a merchant, did not invest in enlarging his stock of music types. Was the market not yet ready for it? It may be that 


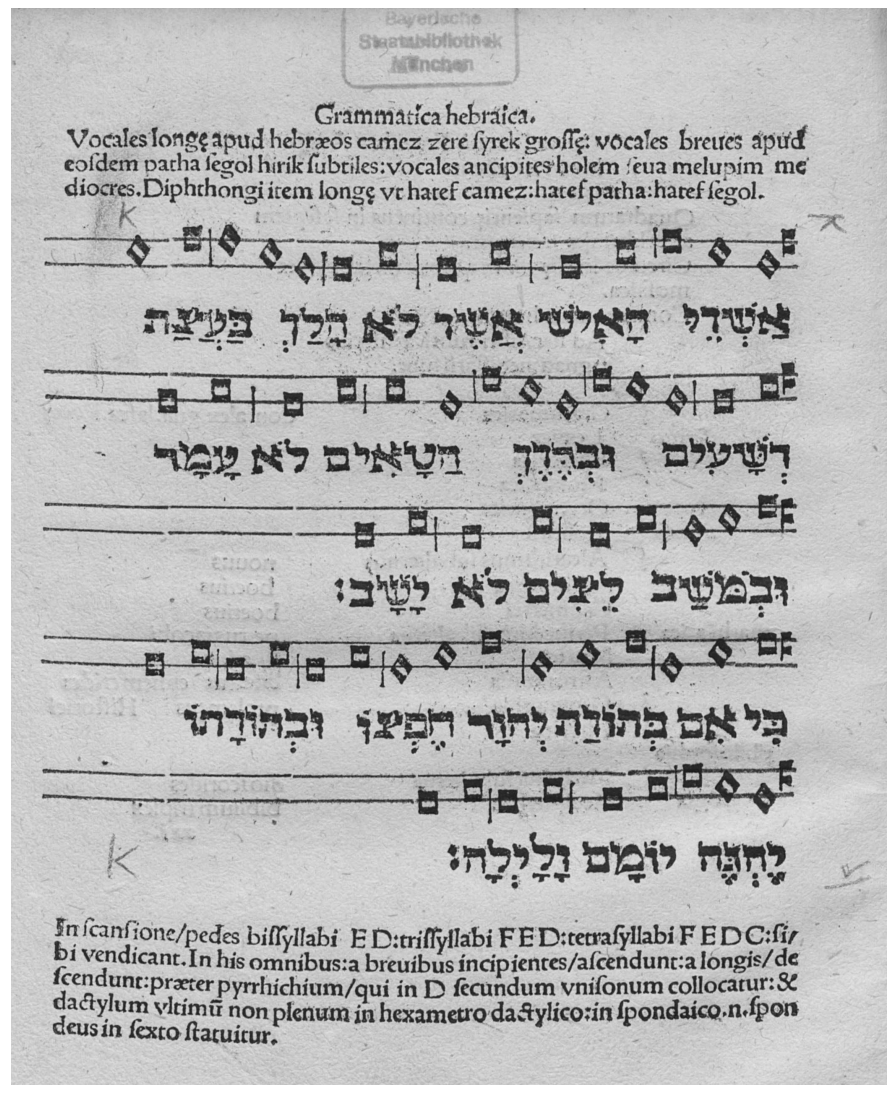

Figure 1.5 Johann Miller. Johannes Foeniseca, Quadratum sapientiae (Augsburg, 1515), vdm 436. Source: Munich, Bayerische Staatsbibliothek, Rar. 1518, fol. [A1].

he simply could not afford the investment. In 1520 he had to shut down his workshop for financial reasons, and declared bankruptcy in $1523 .{ }^{24}$

In the same year, in 1520, a much more ambitious printing project was realised. The Liber selectarum cantionum, a selection of twenty-four motets, has been studied intensively in the last ten years. ${ }^{25}$ It seems that the intellectual forces of the town were bundled into this book as an exceptional bibliophilic enterprise: Peutinger wrote a letter to the readers, Ludwig Senfl collected and edited the music, and the humanist printers Grimm and Wyrsung wrote a learned preface with a dedication to Matthäus Lang, Archbishop of Salzburg. ${ }^{26}$ Both printers also owned a pharmacy in the city. Grimm was also a municipal physician, with an interest in alchemical experiments. To print a book such as the Liber selectarum, containing more than 250 pages of music in folio, a rich font of types had to be produced: not only all musical notes, from maxima to fusa (some in two different shapes, some also in a coloured version), but also ligatures in composite and oblique forms, clefs, rests, custodes, fermatas, mensuration signs and accidentals. They were presumably cast in Grimm's own type foundry. The size of the font is enormous: the staves are $24.5 \mathrm{~mm}$ high (Oeglin's staves measure $15 \mathrm{~mm}$ ), and a minim is $25.5 \mathrm{~mm}$ high (Oeglin's is only $12 \mathrm{~mm}$ ). Remarkable is also the great care that was taken in the proofreading, not only in correcting notes but also in the mise-en-page. The sample in Figure 1.6 shows the same page in two different copies. On the right side (b), the typesetting of the forme has been improved by spelling out Isaac's 
first name in full, by prolonging the third staff, and by placing the tacet part exactly in the middle of the page. Furthermore, several syllables in the text underlay in the lower voice have been adjusted to the music. Many such stop-press corrections occur throughout the book. The enormous effort with which this edition was produced is almost unbelievable, and it is not surprising that this workshop also went bankrupt only a few years later. The music fonts were not used again for several decades. ${ }^{27}$

During the process of dissolving this workshop Simprecht Ruff came into play. Neither Grimm nor Wyrsung were familiar with the practical part of book production, and employed Ruff (active as printer 1517-1526) as head of the workshop. At first Ruff only gave his name in the colophons to keep the output of the press from the creditors, but from 1526 onwards he was the real owner of the workshop. In the same year, he printed a Latin grammar book, De partium orationis inflexionibus compendium (vdm 137) by Theobald Billicanus, which includes twenty-one ode settings. This humanistic publication is assigned to Ruff on the basis of the text font and the initials. It seems to draw on Oeglin's first editions, although the format was even smaller - De partium orationis is in upright octavo - and instead of breves and semibreves, semibreves and minims are used to indicate long and short syllables. The four voices, however, are also in a choirbook layout, with newly cast music fonts (see Figure 1.7). In size they correspond to Oeglin's types; the 'swan-neck' custos and the g-clef also resemble those of Oeglin. However, the minim is half a space
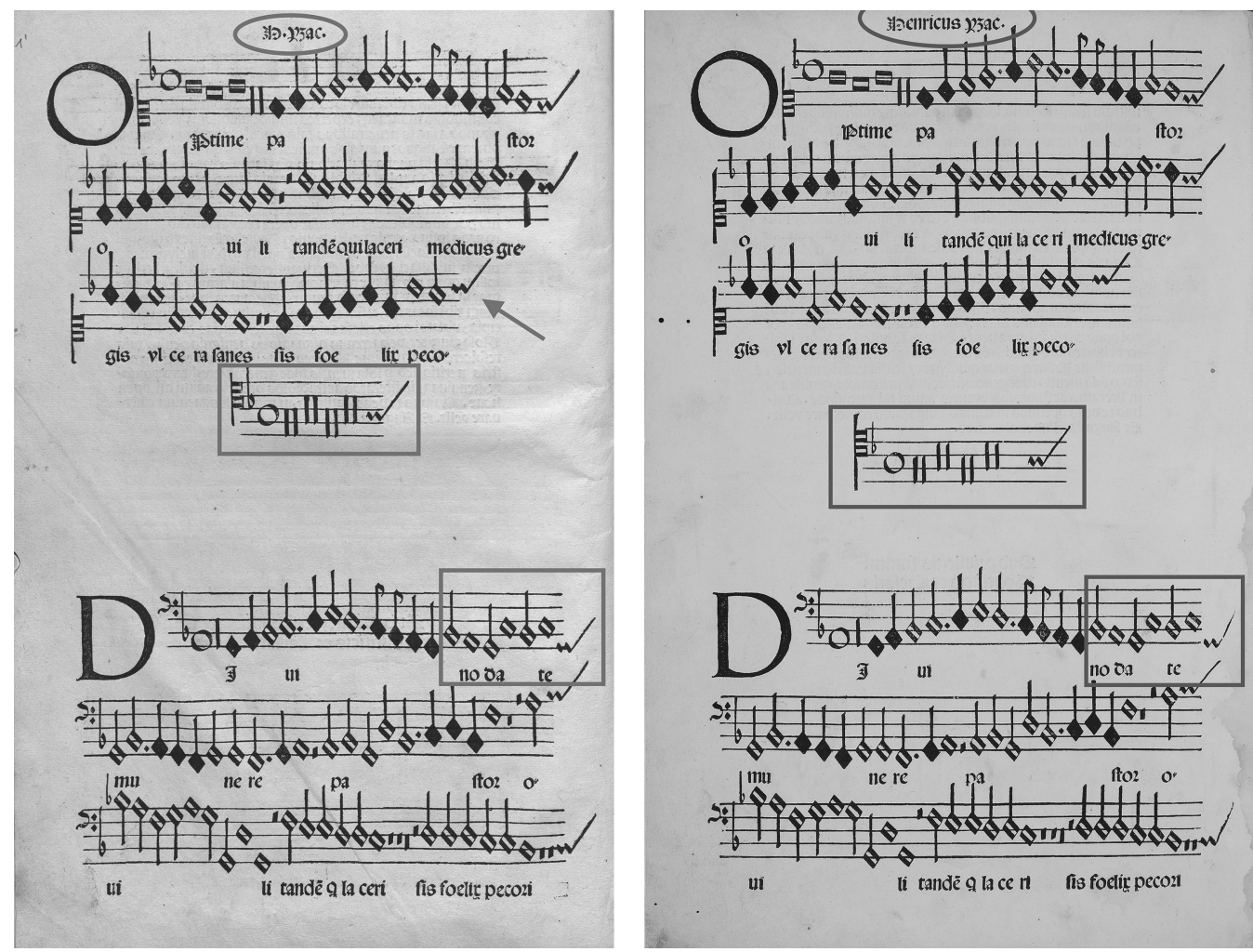

Figure 1.6 Grimm and Wyrsung. Liber selectarum cantionum (Augsburg, 1520), vdm 18, fol. A1 .

Source: (a) Wien, Österreichische Nationalbibliothek, SA.80.E. 4.Mus 27; (b) Augsburg, Staats- und Stadtbibliothek, Tonk Schl 77. 

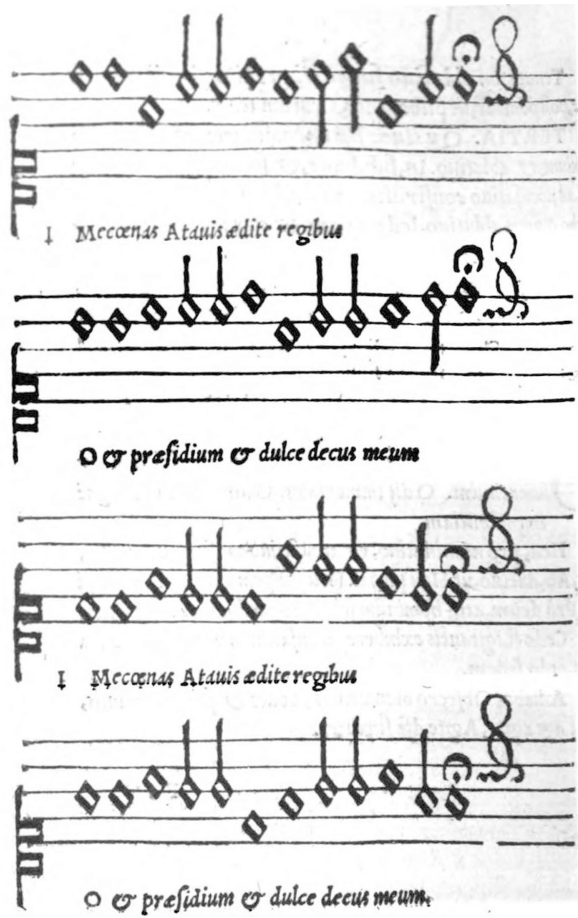

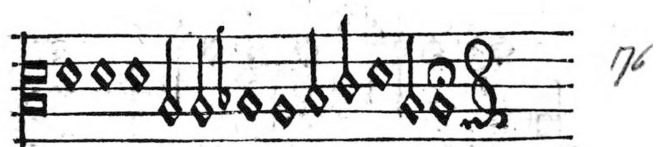

Meconus Atalis adite regibus

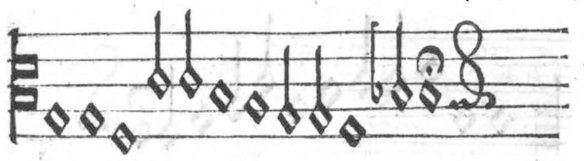

o 0 prefidium 0 dulce decus meum
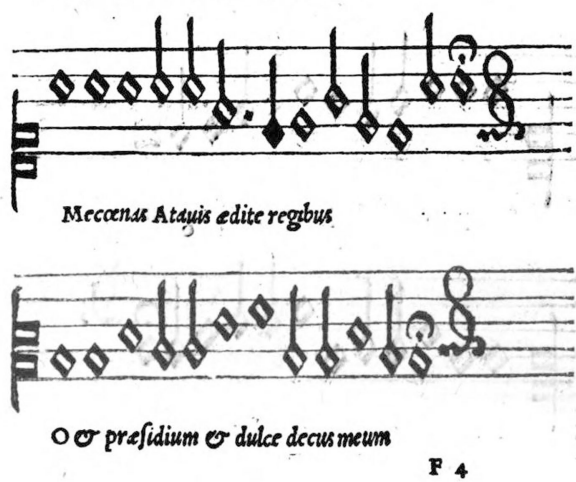

Figure 1.7 Simprecht Ruff. Theobald Billicanus, De partium orationis (Augsburg, 1526), vdm 137. Source: Munich, Bayerische Staatsbibliothek, Mus.th. 2784, fol. F3v-4 ${ }^{\mathrm{r}}$.

longer, and the c-clef, open on the right side, is clearly related to that in the Liber selectarum, in which Ruff must have been involved. ${ }^{28}$

\section{Experimenting in Vienna: Hieronymus Vietor}

East of Augsburg, the printer Hieronymus Vietor (c. 1480-1531) operated workshops in Kraków and Vienna. Vietor, born in Silesia, learnt the printing business in Kraków, transferring to Vienna in 1510, where he worked with Johann Winterburger and Johann Singriener. The former was active in liturgical music printing in double-impression technique, while the latter printed works of music theory and lute tablatures with music examples in woodblock. ${ }^{29}$ With the publication of the Cathemerinon in 1515, Vietor introduced mensural music printing in double impression to Vienna. The humanistic book in upright quarto format contains twelve hymns according to the times of the day, authored by Prudentius, a Christian poet from late antiquity. Four of the hymns are accompanied by melodies, which are displayed in two different styles: three with breves and semibreves, like Oeglin's ode publications; and one with semibreves and minims, according to Ruff's collection (see Figure 1.8, p. 28). The hymns were set to music by Wolfgang Grefinger, organist at St Stephan in Vienna, at the request of the Viennese humanist circle, led by Joachim Vadianus. ${ }^{30}$

The inconsistent notational representation of the hymn settings is matched by an unconventional and unsystematic musical layout. While the voice parts are always notated in one line each, as in a modern score, their designations differ from example to example. In two cases the voice designations are placed at the beginning of the music, above the line 

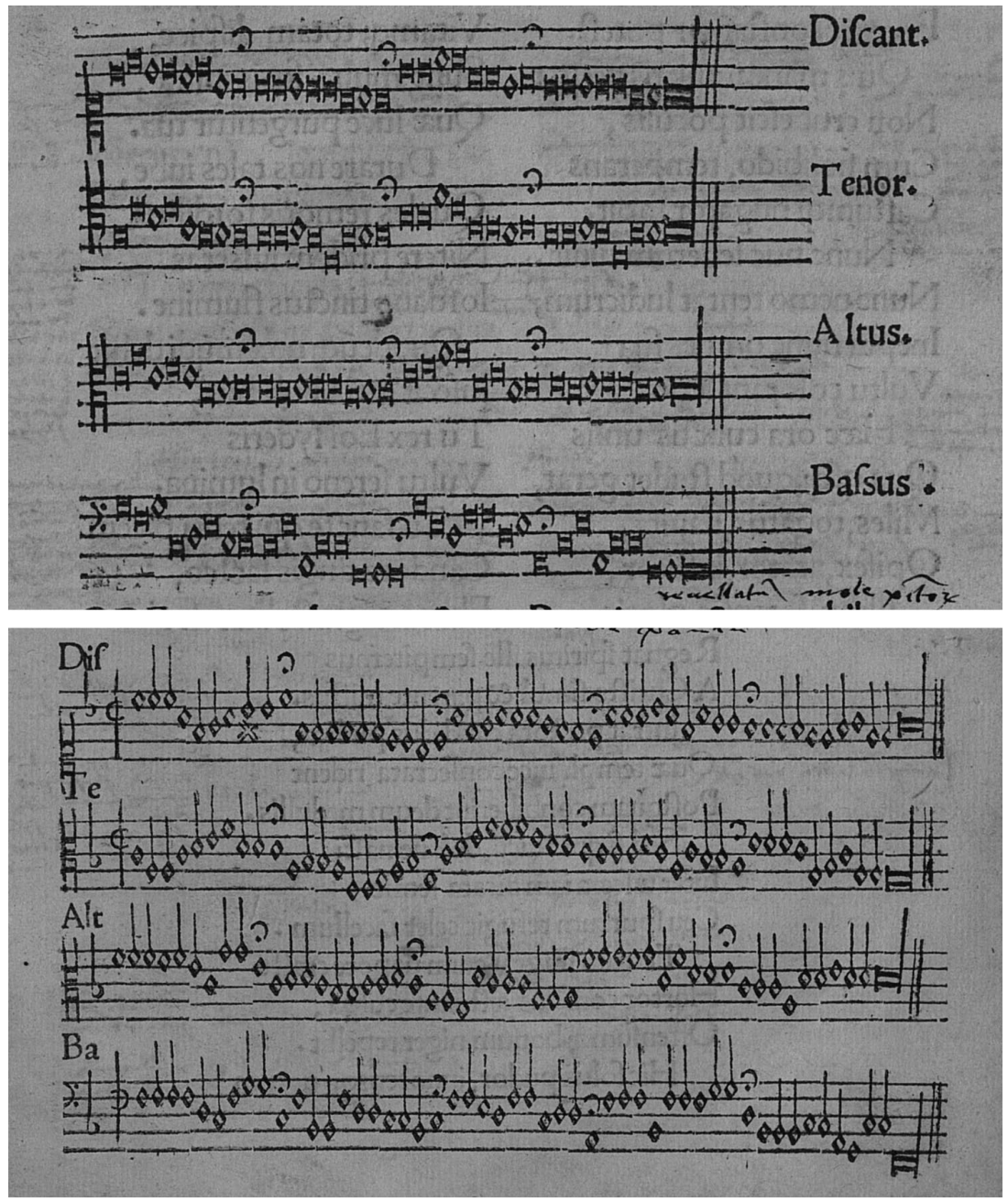

Figure 1.8 Hieronymus Vietor. Cathemerinon (Vienna, 1515), vdm 84.

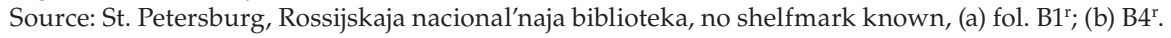

with the uncommon abbreviations 'Dis', 'Te', 'Alt', 'Ba', or fully written out to the left of the staff lines. In two other cases they follow the music in the right margin; once they are written out, once indicated with the initials ' $\mathrm{D}^{\prime}$, ' $\mathrm{T}$ ', ' $A$ ', ' $\mathrm{B}$ ' (see Figure 1.8). The printing of the notation looks quite uneven: the shape of the f-clef of the Bassus is very simple, some final longas are crooked, and several final double bars are slightly skewed. ${ }^{31}$ Moreover, the staff lines are composed of shorter sections, reinforcing the unsettled character. In the heavily annotated copy from the Russian National Library at St Petersburg, the notation looks tiny. ${ }^{32}$ Indeed, it is much smaller than the music fonts we have seen so far: the height of the staff is only $10 \mathrm{~mm}$. By contrast, Oeglin's staff is $14 \mathrm{~mm}$ high, Ruff's $15 \mathrm{~mm}$, Grimm and Wyrsung's $24 \mathrm{~mm}$.

All in all, the printed music in the Cathemerinon seems somewhat experimental and unprofessional, and Vietor seems not to have followed up on this endeavour. He returned to 
set up another workshop at Kraków in 1518. His brother maintained his book shop at the old Fleischmarkt, and Singriener, who had a share in the same shop, took over his typographical materials. The music font, however, was not used again. ${ }^{33}$

\section{A third start at Mainz: Peter Schöffer the Younger}

While Vietor was a geographical outlier, our last printer comes from the very centre of German book printing, from Mainz. Peter Schöffer the Younger (c. 1480-1547) was born into a family of printers. His father Peter the Elder was involved in the production of the legendary 1452 Bible from Gutenberg's workshop, and took over the firm when Gutenberg failed. While the older brother Johann inherited the workshop, Peter Schöffer the Younger worked as a type cutter and founder until he opened his own printing shop, where he experimented with music printing. In 1512 he started his production with a tablature book named Tabulaturen etlicher Lobgesang und Lidlein uff die Orgel, und Lauten. For this collection, which also contains pieces for lute and voices, he had to cast type for early German keyboard and lute tablature, as well as for mensural notation. Schöffer was clearly aware of the high quality of the polyphonic music books from Italy and imitated Petrucci's fonts. I have shown elsewhere that the shapes of the musical signs and their dimensions were modelled 1:1 on the products of the Italian paragon. ${ }^{34}$ Schöffer's second publication, the songbook Quinquagena carminum (1513), was even a reprint of Petrucci's Canti B. ${ }^{35}$

The comparably rich output over the next twenty-seven years comprises a broad repertoire: after lute and keyboard tablatures, German and French song books, polyphonic German song and hymns, a work on music theory, motets, a lament and a Magnificat collection were in his programme. Schöffer also printed Lutheran music, including three editions of the polyphonic hymn book by Johann Walter (see Appendix 1.2). The example in Figure 1.9 is a page from his last music book, a collection of motets for five voices,

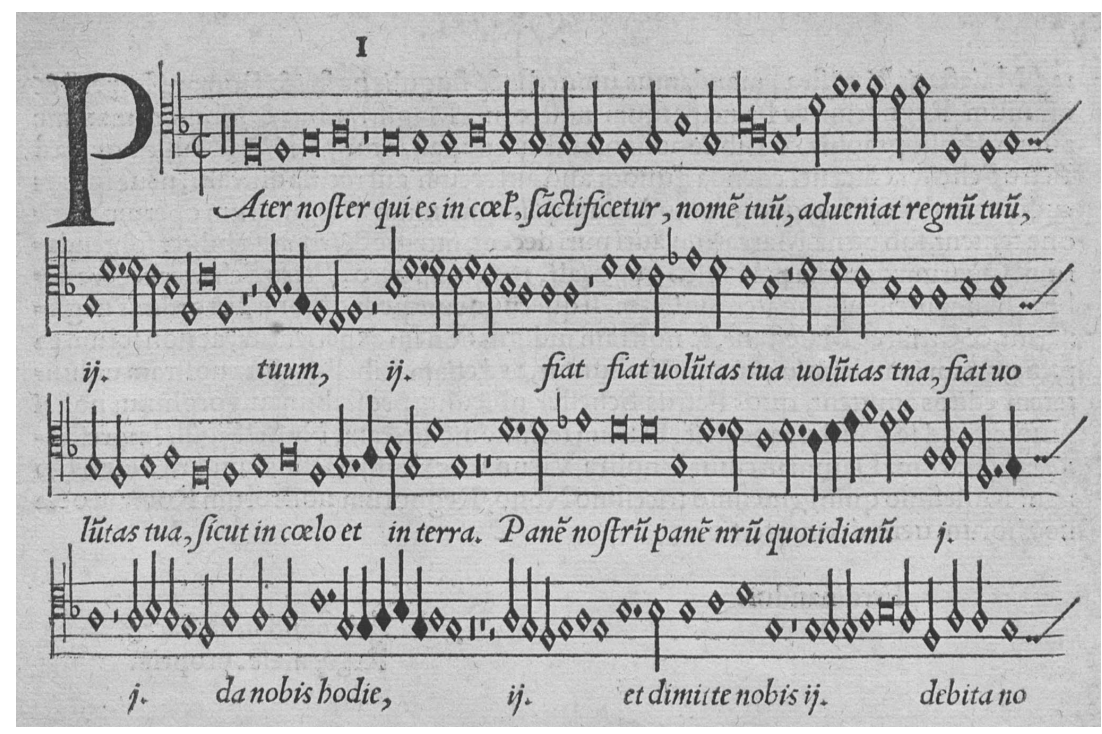

Figure 1.9 Peter Schöffer the Younger. Cantiones quinque vocum selectissimae (Strasbourg, 1539), vdm 44. Source: Munich, Bayerische Staatsbibliothek, Mus.pr. 48, tenor, Aa2v. 
including a repertoire from the cathedral of Milan. With its balance, its diligence, its perfect proportions and fine technical execution it is a magnificent example of Schöffer's high aesthetic standards.

Moreover, Peter Schöffer the Younger seems to be the only polyphonic music printer also interested in producing liturgical music. While his brother Johann printed only empty staff lines in some of his psalters, missals and agendas, Peter was involved in printing at least three liturgical books in the second decade of the century, when his first mensural notated music books and the tablature were already out. It is unclear if these editions were printed on commission, or if they represent a second line of his business which however did not gain momentum. ${ }^{36}$

Nevertheless, there is no doubt that Peter Schöffer the Younger was the most significant music printer of his time north of the Alps. He combined the rich tradition of German printing with the new technical advances in polyphonic music printing transmitted from Venice. Like other early printers, Schöffer did not stay in one place. His sympathies for the new religious movement forced him to leave the Roman Catholic city of Mainz, settling first at Worms, and in 1529 at Strasbourg, one of the centres of the Reformation. Schöffer did not adopt the new single-impression technique for printing polyphonic music, introduced by Christian Egenolff in 1532. Consequently, his last musical editions until 1539 seem like monuments from the past, sustaining the highest quality of double impression. He sold his fonts to a printer from the Low Countries who used it for the so called 'Kampen Songbook' (c. 1535). ${ }^{37}$ When Schöffer finally moved to Basel - Mewes' workplace and Oeglin's training centre - in the early 1540s, the circle was complete and the first period of polyphonic music printing in German-speaking lands was over.

\section{Music types and fonts}

For printers who were already involved in printing literary texts, and who possessed a stock of fonts in different sizes and styles, printing musical notation in multiple impression involved an additional investment. In principle, the production of a music font and additional musical signs followed the same technical process as producing letters: the individual notational signs had to be designed, cut on a punch, stamped in a matrix, cast and justified. ${ }^{38}$ The staff lines were printed either from a series of shorter blocks containing five lines, or set from individual metal strips. Both techniques were used in printing chant in liturgical books.

\section{Measurements and formats}

The range of dimensions and aesthetics of the music types that emerged in the Germanspeaking area during the first three decades is striking, as shown in Table 1.1. Before we go into detail, we should discuss the problem of the measurement. Even if an electronic caliper is used to measure individual elements, certain parameters make accurate measurement difficult. First of all there are material reasons: the ink is not absorbed evenly by the moistened paper, so that staff lines or note stems are not of the same thickness throughout. Furthermore, the printed paper shrinks slightly when drying, which means that the same characters can shrink to different degrees, even if only to the extent of tenths of a millimetre. And finally, the human eye must be sharp enough to determine boundaries in the micro range with the measuring instrument. To counteract these difficulties, in the $v d m$ project we measure the staff from the middle of the lowest line to the middle of the highest line and round all our measurements up or down to half a millimetre. 
Table 1.1 Measurement (height) formats in chronological order (broadsheets are not included)

\begin{tabular}{|c|c|c|c|c|c|c|c|c|c|}
\hline \multirow[t]{2}{*}{ Printer } & \multicolumn{3}{|c|}{ Measurements } & \multicolumn{6}{|c|}{ Formats } \\
\hline & Staff & Minim & Relation & $2^{\circ}$ & $4^{\circ}$ & $4^{\circ}$ obl. & $6^{\circ}$ & $8^{\circ}$ & $8^{\circ}$ obl. \\
\hline Mewes & 14 & 11 & 1.27 & & & $x$ & & & \\
\hline Oeglin & 15 & 12 & 1.25 & $x$ & $x$ & & $\mathrm{x}$ & & $x$ \\
\hline Schöffer & 10 & 11 & 0.90 & $x x$ & & $x x$ & $\operatorname{xxxxxxx}$ & & $x x x$ \\
\hline Vietor & 10 & $9^{a}$ & 1.11 & & $x$ & & & & \\
\hline Miller & $(3.5)^{\mathrm{b}}$ & $-^{c}$ & - & & $x$ & & & & \\
\hline $\begin{array}{l}\text { Grimm \& } \\
\text { Wyrsung }\end{array}$ & 24.5 & 25.5 & 0.96 & $x$ & & & & & \\
\hline Ruff & 15 & 13 & 1.15 & & & & & $x$ & \\
\hline
\end{tabular}

${ }^{a}$ The number is calculated in relation to the staff since the inspected copy PL-WRzno is missing the page with the ode notated in semibreves.

bHeight of two staff lines.

'Breve: $3.5 \mathrm{~mm}$ high.

Determinative criteria for the identification of music types are the height of the staff, the length of the stems and their relationship to each other. In the chronologically arranged Table 1.1, three different basic sizes of staves can be identified. The first printers, Mewes and Oeglin, opted for a medium-sized staff, between 14 and $15 \mathrm{~mm}$. While the music in the oblong quarto format of Mewes' publication seems rather crowded, the notes for the folio format of Oeglin's first edition, as mentioned above, are actually too small for the page (cf. Figures 1.2-1.4). Even the latest printer, Simprecht Ruff, uses a staff of $15 \mathrm{~mm}$ on average, but now for a work in octavo format, in which the notes appear oversized in relation to the text beneath (see Figure 1.7).

Peter Schöffer the Younger and Hieronymus Vietor preferred a medium staff size of $10 \mathrm{~mm}$, which was adopted from Petrucci's publications. As with the Italian model, both pioneers printed in quarto format for the first time. Later in his career, Schöffer preferred the somewhat smaller, almost square sexto format that Oeglin introduced with his songbook Aus sonderer künstlicher Art in 1512. ${ }^{39}$ Only three of Schöffer's songbooks are in octavo format, while the two editions of Johannes Frosch's theoretical treatise were presumably both in folio format. ${ }^{40}$

The printed works of Miller and the Grimm and Wyrsung partnership are exceptions in various respects. While Miller only needs two staff lines to depict the Hebrew melody, Grimm and Wyrsung's collection of motets in the large choirbook format shows by far the largest dimensions of staff systems and staves. As with manuscripts of the time, in this case the page size corresponds perfectly to the staff height. The flexible arrangement of the staves and the extremely accurate typeface more closely resemble a hand-written book than most other printed ones from the time. ${ }^{41}$

In order to determine the dimension of the notational signs, the height of the minima is measured and this number is compared to the staff height. This can either be expressed numerically or determined by the naked eye by specifying the number of spaces into which the note stems are inserted. In the standardised notation pattern in use today, the stem of a note in the first interspace ends exactly with the top staff line. The types of Schöffer (and Petrucci) correspond relatively precisely to this ideal. In mathematical terms, this relation would be 1.0. The fact that Schöffer's ratio is slightly lower (0.90) is due to the rhombic shape of the note head, which protrudes slightly above the line. Grimm and Wyrsung are 
closest to this ideal (0.96). In Vietor's font, the stem of the note ends shortly before the top line (1.11). The stems of the notes in Ruff's font occupy two and a half spaces (1.15). In those of Oeglin and Mewes they are only two spaces high. With the dimensions 1.25 and 1.27, they deviate the most from the current standard.

\section{Individual fonts}

In addition to the dimensions, individual note shapes can also characterise a font. In Appendix 1.1, individual staves of the seven fonts are presented in relative proportion to one another, while in Appendix 1.3, selected individual characters are compared in a type repertory. Both representations are arranged chronologically.

In respect of the note heads, we already notice clear differences between the music fonts. For example, the breves of the first four printers, from Oeglin to Vietor, are square and equipped with serifs; Miller's breve is completely unadorned and Grimm's breve is wider than it is high. Ruff's font contains no breves, and longs only as final notes. ${ }^{42}$ The semibreves of the individual printers are more similar to each other, although this sign is particularly slim for Mewes and particularly oblique for Grimm. More characteristic, on the other hand, are the note stems, shown here as they occur on minimas. With Mewes, Schöffer and Ruff they are equally fine. In Oeglin's font, the upper end of the neck ends with a small hook, as seen often in woodcuts. The music stems in Grimm and Wyrsung's font are peculiar in other ways. Since they begin somewhat to the right of the tip of the note head, they give the impression that they have been added separately. In addition, they are not all equally thick, and appear shortened when individual pages are corrected with regard to the text lines above them (cf. Figure 1.6, fourth and fifth minima at the beginning of the second line, first and sixth minima in the third line). ${ }^{43}$ The differences in the note flags are considerable: in Mewes, Oeglin and Schöffer, the flags form a triangle. In Mewes, however, the triangle does not close at the neck of the note, but passes it with a flourish. Grimm, on the other hand, uses only small flags, as in modern notational convention.

The range of variation between the fonts of the individual printers is greatest in the area of clefs. Only Oeglin, Schöffer and Grimm had c-, f- and g-glefs. Miller and Vietor had only cand f-clefs in their type repertoire; Ruff had only c- and g-clefs; and Miller had only a simple f-clef to determine the pitch. The c-clef, which consist of two breves with vertical boundary lines, differ mainly in the right boundary line. At Mewes it is bent inwards in a second variant. In Oeglin's font there is a long and a short variant. With Schöffer the right boundary line is shorter than the left one. With Vietor the line between the two breves is missing. In the fonts of Grimm and Ruff, the c-clefs remain without any boundary line at all; their shape resembles rabbit's teeth. ${ }^{44}$ The basis of the g-clef is always the capital letter G, which is provided with additional loops. Here the characteristic shapes of Oeglin and Schöffer form one group and the shapes of Grimm and Ruff form another. In the fonts of Mewes, Oeglin, Schöffer and Grimm, the f-clefs are a combination of notes (long and two semibreves with stems up and down). Grimm also has a second variant, which is based on a symbolised representation of the letter $\mathrm{f}$, corresponding to the f-clef used today. Vietor uses the same character. Miller, on the other hand, has a simple version of the same clef with the capital letter F.

Among the strongest markers of a music notation are the custodes. Here it is above all the continuing line after the zigzag sign that makes the difference. This line is quite straight in the fonts of Schöffer and Grimm, though the angle is somewhat steeper in that of Grimm. The custodes in Mewes' font are slightly curved. In that of Oeglin, this line is S-shaped and reminiscent of a swan's neck. Ruff bends this S-line back once again, so that his custos resembles the g-clef of Oeglin or Schöffer. 
Other characteristic special characters are fermatas and accidentals. While the fermata sign in the fonts of Mewes and Grimm are quite symmetrical and straight, those of Schöffer and Vietor point slightly to the right. Oeglin's fermata is small, and that of Ruff is bulbous. Only four printers use slightly different sharp signs; Schöffer had an earlier and a later shape available.

\section{Other features}

Having trained our eye to recognise the details of each font, we shall now examine how the note appears when set in entire passages and printed pages. Here, the density of a sequence of notes is decisive. Three categories can also be identified here. Mewes and Vietor set their notes very closely, as does Schöffer, an impression reinforced by the long note stems. In Oeglin's books there seems to be hardly any space between the notes, although density of notes is more irregular. Only in Grimm's choirbook and the ode collection of Ruff are the notes evenly spaced.

Further criteria for comparison would be indents for initials at the beginning of a voice, the presence and composition of ligatures, the use of repetition signs and ledger lines, various mensural and proportion signs, signa congruentiae and the design of the staves. Without going into more detail, I would like to draw attention to the differences in size of the various fonts. This obviously depends on the printed musical repertoire. Miller could set the Hebrew language melody using only three characters: breve, semibreve and f-clef. Slightly larger fonts, of ten and fourteen characters respectively, were required by Vietor and Ruff for their ode settings. Mewes, Oeglin, Schöffer and Grimm had complete fonts of up to forty characters. Their portfolio included masses, motets and secular songs, whose notation requires many more musical characters.

\section{Summary}

In contrast to Petrucci, who intended to establish a new market for polyphonic printed music, German printers seemed to print music only as a side line besides their literary books. Although the technique of double impression was already used for music in liturgical books, none of the printers were directly affiliated with those workshops, though they had personal contacts with them.

Augsburg, home to the workshops of Oeglin, Miller, Grimm and Ruff, was an early centre for mensural music printing, promoted by German humanist circles. Vietor was connected to Viennese humanistic circles, closely related to those in Augsburg by virtue of Maximilian's peripatetic court. Given the close personal networks between printers, it is astonishing that there was no direct exchange of music fonts - only a few borrowings in type design. All these printers had individual fonts, applied for a single edition or just a few. That they did not continue with music printing might be due to their unstable and risky financial background. Like Gutenberg and many other early printers, some even went bankrupt. Only Peter Schöffer the Younger, the master of music printing from Mainz, developed a more extensive programme of musical editions, with a broad repertoire over a longer period of time, yet even his output is not overwhelming. Moreover, his font was the only one that was transferred to another printer outside the German-speaking lands, at a time when multiple-impression technique was already obsolete.

Polyphonic music printing needed a simpler technique and a clearly defined, stable market if it was to succeed. This only happened a few decades later, once the turbulence of the early Reformation had calmed down and the single-impression technique was 
introduced. The shift to the new technique also entailed the beginning of mass production. New printers entered business and the centres of music printing moved to other cities. Nuremberg came to dominate the market, with Wittenberg following, while Augsburg fell into third place. As far as we know, the printers of Mainz and Vienna did not take up single-impression music printing at all, and those of Strasbourg started only very late. ${ }^{45}$

The pioneer printers of mensural notation in German-speaking lands, who used the difficult multiple-impression technique, also began a tradition in the design of music fonts. While Schöffer the Younger found his model in Petrucci's music books, all other German printers developed their own style. In general, the dimensions of the fonts were orientated on the format and the repertoire to be printed. Staff heights ranged from 10 to almost $25 \mathrm{~mm}$. The aesthetics of the fonts, the proportion of the type measurements, the mise-en-page, the format and the printed area establish the individual character of a given printing workshop, an individuality far from the standard appearance of music notation developed much later. For us, in retrospect, this counts as a rich heritage and a cultural achievement of its own.

\section{Appendix 1.1 Overview of music type fonts with measurements (height of staff and minim in millimetres) and relative proportions}

Mewes

$14 / 11$

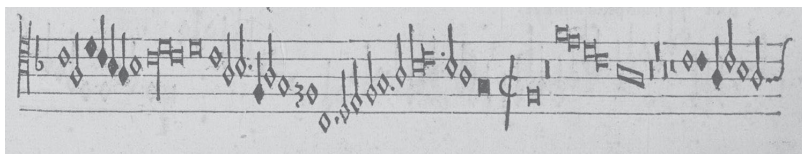

Oeglin

$15 / 12$

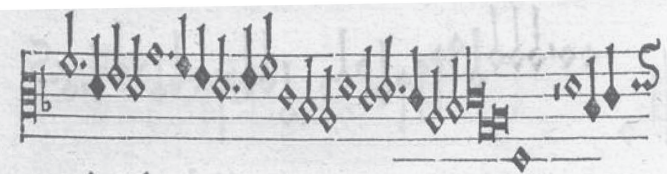

Schöffer

$10 / 11$

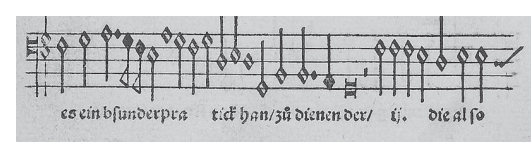

Vietor

10/9

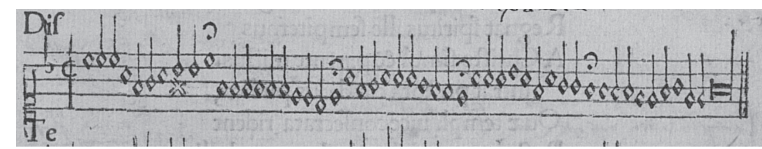

Miller

$-1-$

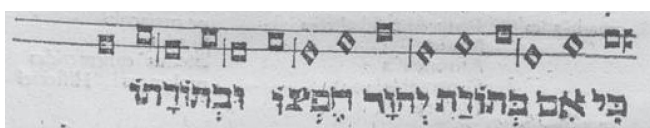

Grimm

$24.5 / 25$

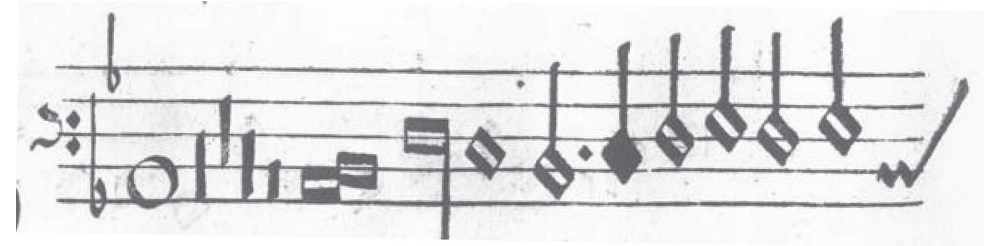

Ruff

15/13

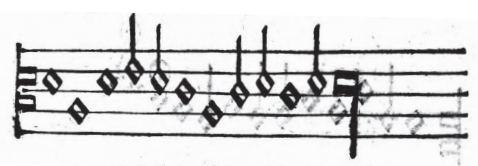




\section{Appendix 1.2 Chronological list of editions with mensural music printed in double-impression technique}

\begin{tabular}{|c|c|c|c|c|c|}
\hline Year & Author title & Place & Printer & Source type & vdm \\
\hline [1507] & $\begin{array}{l}\text { Jacob Obrecht } \\
\text { Concentus harmonici quattuor } \\
\text { missarum }\end{array}$ & Basel & Gregor Mewes & $\begin{array}{l}\text { Polyphonic } \\
\text { music book }\end{array}$ & 630 \\
\hline 1507 & $\begin{array}{l}\text { Petrus Tritonius } \\
\text { Melopoiae sive harmoniae } \\
\text { tetracenticae }\end{array}$ & Augsburg & Erhard Oeglin & $\begin{array}{l}\text { Humanist } \\
\text { book }\end{array}$ & 55 \\
\hline 1507 & $\begin{array}{l}\text { Petrus Tritonius } \\
\text { Harmoniae super odis Horatii Flacci }\end{array}$ & Augsburg & Erhard Oeglin & $\begin{array}{l}\text { Humanist } \\
\text { book }\end{array}$ & 108 \\
\hline c. 1510 & O Sakrament der Heiligkeit & Augsburg & Erhard Oeglin & Broadsheet & 124 \\
\hline 1512 & Aus sonderer künstlicher Art & Augsburg & Erhard Oeglin & $\begin{array}{l}\text { Polyphonic } \\
\text { music book }\end{array}$ & 11 \\
\hline 1512 & [Sixty-eight songs] & [Augsburg] & [Erhard Oeglin] & $\begin{array}{l}\text { Polyphonic } \\
\text { music book }\end{array}$ & 14 \\
\hline 1512 & $\begin{array}{l}\text { Arnold Schlick } \\
\text { Tabulaturen etlicher Lobgesang und } \\
\text { Lidlein uff die Orgeln und Lauten }\end{array}$ & Mainz & $\begin{array}{l}\text { Peter Schöffer the } \\
\text { Younger }\end{array}$ & $\begin{array}{l}\text { Tablature } \\
\text { book }\end{array}$ & 12 \\
\hline 1513 & Quinquagena carminum & Mainz & $\begin{array}{l}\text { Peter Schöffer the } \\
\text { Younger }\end{array}$ & $\begin{array}{l}\text { Polyphonic } \\
\text { music book }\end{array}$ & 15 \\
\hline 1513 & [Songs for 3-4 voices] & Mainz & $\begin{array}{l}\text { Peter Schöffer the } \\
\text { Younger }\end{array}$ & $\begin{array}{l}\text { Polyphonic } \\
\text { music book }\end{array}$ & 13 \\
\hline 1515 & $\begin{array}{l}\text { Aurelius Prudentius Clemens } \\
\text { Cathemerinon }\end{array}$ & Vienna & $\begin{array}{l}\text { Hieronymus } \\
\text { Vietor }\end{array}$ & $\begin{array}{l}\text { Humanist } \\
\text { book }\end{array}$ & 84 \\
\hline 1515 & $\begin{array}{l}\text { Johannes Foeniseca } \\
\text { Quadratum sapientiae }\end{array}$ & Augsburg & Johann Miller & $\begin{array}{l}\text { Theory book/ } \\
\text { Humanist } \\
\text { book }\end{array}$ & 436 \\
\hline 1517 & [Thirty-six songs] & Mainz & $\begin{array}{l}\text { Peter Schöffer the } \\
\text { Younger }\end{array}$ & $\begin{array}{l}\text { Polyphonic } \\
\text { music book }\end{array}$ & 16 \\
\hline c. 1518 & $\begin{array}{l}\text { Hans von Schnore } \\
\text { Ein newes Lied in Hessen gmacht }\end{array}$ & [Mainz] & $\begin{array}{l}\text { [Peter Schöffer the } \\
\text { Younger] }\end{array}$ & Pamphlet & 889 \\
\hline 1520 & $\begin{array}{l}\text { Ludwig Senfl (ed.) } \\
\text { Liber selectarum cantionum quas } \\
\text { vulgo mutetas appellant }\end{array}$ & Augsburg & $\begin{array}{l}\text { Sigmund Grimm } \\
\text { \& Marx Wyrsung }\end{array}$ & $\begin{array}{l}\text { Polyphonic } \\
\text { music book }\end{array}$ & 18 \\
\hline 1525 & $\begin{array}{l}\text { Johann Walter } \\
\text { Geystliche Gsangbüchlin }\end{array}$ & [Worms] & $\begin{array}{l}\text { Peter Schöffer the } \\
\text { Younger }\end{array}$ & $\begin{array}{l}\text { Polyphonic } \\
\text { music book }\end{array}$ & 111 \\
\hline 1526 & $\begin{array}{l}\text { [Anarg von Wildenfels] } \\
\text { O Herre Gott, dein göttlich Wort }\end{array}$ & [Worms] & $\begin{array}{l}\text { [Peter Schöffer the } \\
\text { Younger] }\end{array}$ & Broadsheet & 202 \\
\hline 1526 & $\begin{array}{l}\text { Theobald Billicanus } \\
\text { De partium orationis inflexionibus } \\
\text { compendium }\end{array}$ & [Augsburg] & [Simprecht Ruff] & $\begin{array}{l}\text { Humanist } \\
\text { book }\end{array}$ & 137 \\
\hline [1532] & $\begin{array}{l}\text { Johannes Frosch } \\
\text { Rerum musicarum opusculum } \\
\text { rarum ac insigne }\end{array}$ & [Strasbourg] & $\begin{array}{l}\text { Peter Schöffer the } \\
\text { Younger }\end{array}$ & Theory book & 1534 \\
\hline 1534 & $\begin{array}{l}\text { Sixt Dietrich } \\
\text { Epicedion Thomae Sporeri } \\
\text { musicorum principis }\end{array}$ & Strasbourg & $\begin{array}{l}\text { Peter Schöffer } \\
\text { the Younger \& } \\
\text { Matthias Apiarius }\end{array}$ & $\begin{array}{l}\text { Polyphonic } \\
\text { music book }\end{array}$ & 62 \\
\hline 1534 & $\begin{array}{l}\text { Johann Walter } \\
\text { Wittenbergische Gsangbüchli }\end{array}$ & Strasbourg & $\begin{array}{l}\text { Peter Schöffer } \\
\text { the Younger \& } \\
\text { Matthias Apiarius }\end{array}$ & $\begin{array}{l}\text { Polyphonic } \\
\text { music book }\end{array}$ & 112 \\
\hline 1535 & $\begin{array}{l}\text { Sixt Dietrich } \\
\text { Magnificat octo tonorum liber } \\
\text { primus }\end{array}$ & Strasbourg & $\begin{array}{l}\text { Peter Schöffer } \\
\text { the Younger \& } \\
\text { Matthias Apiarius }\end{array}$ & $\begin{array}{l}\text { Polyphonic } \\
\text { music book }\end{array}$ & 63 \\
\hline
\end{tabular}


Appendix 1.2 continued

\begin{tabular}{|c|c|c|c|c|c|}
\hline Year & Author title & Place & Printer & Source type & vdm \\
\hline 1535 & $\begin{array}{l}\text { Johannes Frosch } \\
\text { Rerum musicarum opusculum } \\
\text { rarum ac insigne }(a) /(b)\end{array}$ & Strasbourg & $\begin{array}{l}\text { Peter Schöffer } \\
\text { the Younger \& } \\
\text { Matthias Apiarius }\end{array}$ & Theory book & $\begin{array}{l}564 \\
637\end{array}$ \\
\hline 1536 & $\begin{array}{l}\text { Fünff und sechzig teutscher Lieder, } \\
\text { vormals imm Truck nie ussgangen }\end{array}$ & Strasbourg & $\begin{array}{l}\text { Peter Schöffer } \\
\text { the Younger \& } \\
\text { Matthias Apiarius }\end{array}$ & $\begin{array}{l}\text { Polyphonic } \\
\text { music book }\end{array}$ & 27 \\
\hline 1537 & $\begin{array}{l}\text { Sixt Dietrich } \\
\text { Magnificat octo tonorum liber } \\
\text { primus }\end{array}$ & Strasbourg & $\begin{array}{l}\text { Peter Schöffer } \\
\text { the Younger \& } \\
\text { Matthias Apiarius }\end{array}$ & $\begin{array}{l}\text { Polyphonic } \\
\text { music book }\end{array}$ & 64 \\
\hline 1537 & $\begin{array}{l}\text { Johann Walter } \\
\text { Wittenbergische Gsangbüchli }\end{array}$ & Strasbourg & $\begin{array}{l}\text { Peter Schöffer } \\
\text { the Younger \& } \\
\text { Matthias Apiarius }\end{array}$ & $\begin{array}{l}\text { Polyphonic } \\
\text { music book }\end{array}$ & 113 \\
\hline 1539 & $\begin{array}{l}\text { Cantiones quinque vocum } \\
\text { selectissimae / Mutetorum liber } \\
\text { primus }\end{array}$ & Strasbourg & $\begin{array}{l}\text { Peter Schöffer the } \\
\text { Younger }\end{array}$ & $\begin{array}{l}\text { Polyphonic } \\
\text { music book }\end{array}$ & 44 \\
\hline
\end{tabular}

\section{Appendix 1.3 Type repertory for multiple-impression music printing (selection, not to scale)}

\begin{tabular}{|c|c|c|c|c|c|c|c|}
\hline & Mewes & Oeglin & Schôffer & Vietor & Miller & Grimm & Ruff \\
\hline \multicolumn{8}{|l|}{ NOTES } \\
\hline breves & II & $\forall$ & $\#$ & E & E & $\equiv$ & - \\
\hline $\begin{array}{l}\text { semi- } \\
\text { trevese }\end{array}$ & $\frac{}{a}$ & $\underline{5}$ & $\mathbf{z}$ & $\Delta$ & \$ & $\$$ & $\bar{\Sigma}$ \\
\hline minimac & 产 & 王 & 表 & $\overline{1}$ & - & 王 & 卦 \\
\hline 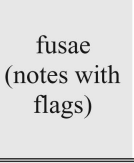 & $\frac{f}{2}$ & f & $\frac{t}{2}$ & - & - & f & - \\
\hline \multicolumn{8}{|l|}{ CLEFS } \\
\hline c-llef & $\frac{H}{1}$ & 基直 & $\bar{E}$ & 基 & - & E & $E$ \\
\hline g-clef & - & 章 & $\begin{array}{l}8 \\
8 \\
6\end{array}$ & - & - & $\overline{\bar{s}}$ & $\underline{E}$ \\
\hline
\end{tabular}




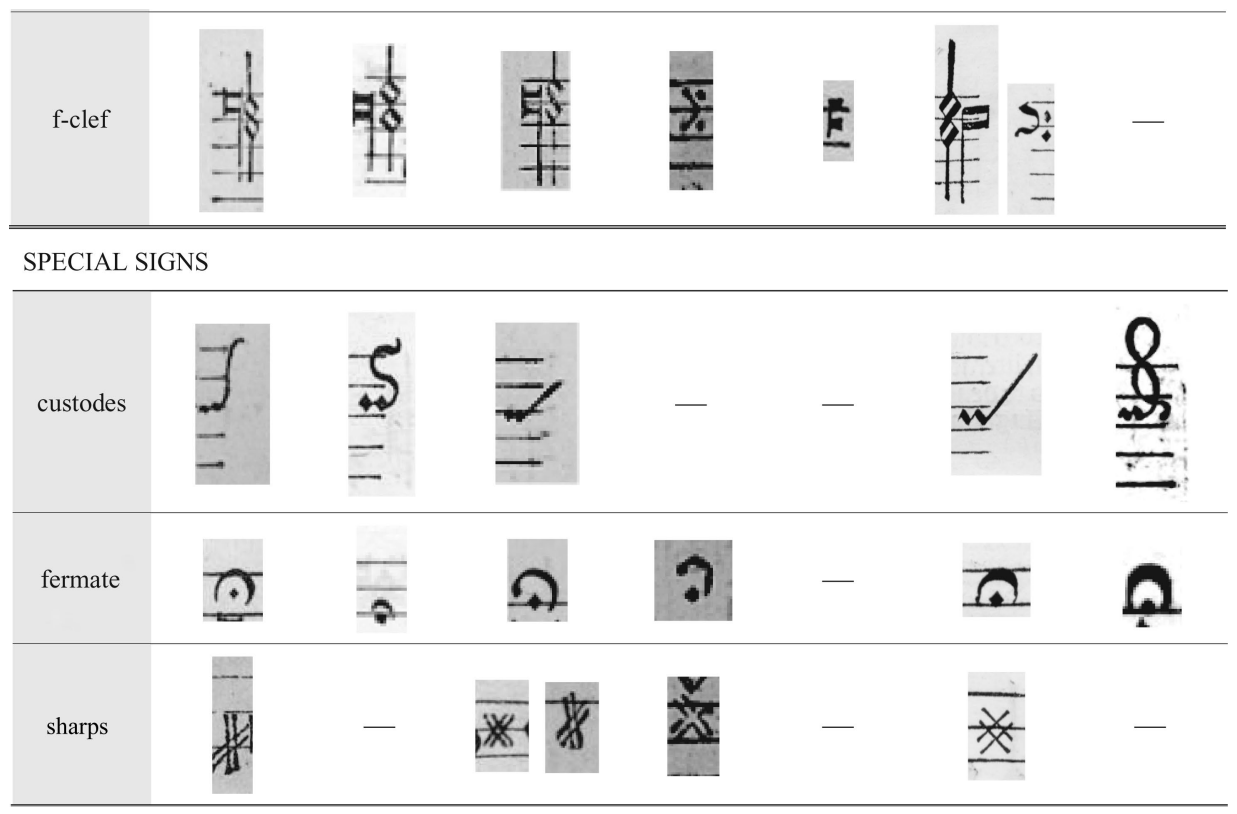

\section{Notes}

1 Duggan, Italian Music Incunabula; Krummel, 'Early German Partbook Type Faces'.

2 See Stijnman and Savage, Printing Colour 1400-1700.

3 See, for instance, fol. B5v in the Paris copy (F-Pn Rés.B.1028) of Psalterium ordinis S. Benedicti de observantia Bursfeldensi (Mainz: Johann Schöffer, 1516), vdm 290. Here the staff lines, red text and red initial are about $6 \mathrm{~mm}$ too high in relation with the black text, which looks very confusing. This edition has only empty staff lines; the musical notation was to be added by hand.

4 For a more detailed description of the printing process with two colours, see Gaskell, A New Introduction, 137-139; Giselbrecht and Savage, 'Printing Music'.

5 See, for instance, the Graduale Romanum, printed in Augsburg by Erhard Ratdolt between 1494 and 1498 (vdm 1082). The colophon of this book mentions Sixtus Haug as editor: 'Hoc opus graduale dicier vulgo solitum: permaximis \& cura \& solicitudine Magistri Sixti haugen revisum \& castigatum [...]' (fol. 116 $)$.

6 Graduale Romanum ([Constance?], [c. 1470-1473] [vdm 1107]). Only two copies survive: a complete one in the British Library, London; and seven leaves in the University Library of Tübingen, detached from a binding of another book.

7 The numbers are taken from $v d m$, accessed on 18 January 2019. The list here only includes cities where more than two known editions were printed.

8 The only possible book would be a Missale Moguntinum, printed by Peter Schöffer the Elder in 1493 (vdm 1449). The Eucharistic prefaces in this edition are printed with empty staves, but in the first section there are some intonations for Kyrie, Gloria and Credo with printed notes. Since the shape of the notes is quite irregular, they were presumably produced in woodcut. More research has to be done to clarify the printing technique used here.

9 Between 1534 and 1537, Schöffer worked in partnership with Matthias Apiarius. In 1537, Apiarius moved to Berne, where he established his own workshop (see Reske, Die Buchdrucker, 107). Some of his output contained music printed with woodcut (several editions of Lampadius' theory book [vdm 572, 573, 1327, 1328]) or in single-impression technique (for example, the pamphlet Ein hüpsch nüw geystlich Lied [vdm 694]).

10 This number is the result of the search 'Printing technique: multiple impression' combined with 'Notation type: Mensual notation' in $v d m$, accessed on 23 January 2019. The two variant issues of the music treatise Rerum musicarum opusculum rarum ac insigne by Johannes Frosch (vdm 564 and 637) are counted as one item.

11 The database $v d m$ contains several editions only known from historical catalogues with no copies extant. McDonald and Raninen, 'The Songbooks of Peter Schöffer', hypothesise the existence of 
at least two lost song books by Peter Schöffer the Younger. See also Royston Gustavson's chapter in this volume.

12 See also Lodes, 'Concentus, Melopoiae und Harmonie 1507'; Lodes, 'Gregor Mewes' “Concentus harmonici"'. I am grateful to Birgit Lodes for supplying me with relevant chapters of her unpublished study.

13 The printers who produced such books were Bernhard Richel and Michael Wenssler (together with Jacob von Kilchen).

14 This concerns two editions of Niger's Grammatica from 1499 and 1500 (vdm 85 and 131). In two editions of De fide concubinarum in sacerdotes from the beginning of the sixteenth century (vdm 671 and 673) a snippet of chant is integrated into the title woodcut. Jakob Wolff from Pforzheim started to print liturgical books with music in about 1510, and then dominated the Basel market until 1519.

15 I thank my co-editor Grantley McDonald for his expertise.

16 Seibicke, Vornamen, 220.

17 Lodes, 'An anderem Ort, auf andere Art: Petruccis und Mewes' Obrecht-Drucke', Basler Jahrbuch für Historische Musikpraxis XXV (2001), 88-111.

18 Künast, 'Getruckt zu Augspurg', 96-97; Röder, 'Innovation and Misfortune', 465-467.

19 See Lodes, 'Concentus, Melopoiae und Harmonie 1507'.

20 On Rynmann, see Grimm, 'Die Buchführer des deutschen Kulturbereichs', col. 1249-1251, 12801286. On the identity of the toponym 'Canna', see German, 'Der Buchhändler Johannes Rynmann von Öhringen', 156-157.

21 Petrus Tritonius, Melopoiae sive harmoniae tetracenticae (Augsburg: Erhard Oeglin, 1507), vdm 55, fol. A9v. Translation into English by Grantley McDonald.

22 See also McDonald, 'Printing Hofhaimer', and Figure 4.3 of Elisabeth Giselbrecht's chapter in this book.

23 Reske, Die Buchdrucker, 31.

24 Ibid., 33. Künast, 'Getruckt zu Augspurg'.

25 Picker, 'Liber Selectarum Cantionum'; Schlagel, 'The 'Liber Selectarum”; Bator, 'Der Chorbuchdruck'; Schiefelbein, 'Same Same but Different'; Giselbrecht and Savage, 'Glittering Woodcuts'.

26 On the dedication of the book, see Lindmayr-Brandl, 'Magic Music in a Magic Square', 23-29.

27 Reske, Die Buchdrucker, 33-34. Printing material and woodcuts went to Philipp Ulhart the Elder and to Heinrich Steiner, who both also printed music, but Ulhart used single-impression technique and woodcuts, and Steiner only woodcuts. As Royston Gustavson recently has shown, Grimm and Wyrsung's music fonts seem to reappear in seven musical editions in large folio format, each containing a single historical polyphonic mass, produced in the private printing workshop of Count Anton of Isenburg-Büdingen in Ronneburg castle between 1558 and 1560 (Gustavson, Senfl in Print', 290-297). More research has to be done on this issue.

28 Tröster, 'Theobald Billican', 227-230; Reske, Die Buchdrucker, 33-34.

29 Two editions were produced in collaboration between Singriener and Vietor: the theory book $\mathrm{Mu}$ sicorum libri quattuor by Václav Philomathes in 1512 (vdm 422), and the humanist book Scaenica progymnasmata by Johannes Reuchlin in 1514 (vdm 78).

30 For more on the edition and the music, see McDonald, 'The Metrical Harmoniæ', 72-83.

31 The crooked longas and the skewed double bars could have been caused by setting the type too loosely in the forme; alternatively, it is possible that Vietor used the technique of stereotyping. In the latter case, this edition would no longer count as an example of multiple-impression printing. More research needs to be done to determine Vietor's technique.

32 This is also the case in the copy in Wrocław (PL-WRzno XVI.Qu.3272), see Figure 1 at McDonald, 'The Metrical Harmoniæ', 76, where a full page is depicted.

33 Reske, Die Buchdrucker, 965-966.

34 Lindmayr-Brandl, 'Peter Schöffer der Jüngere', 298-302.

35 Although I agree with the argument by McDonald and Raninen ('The Songbooks', 52) that the songbook of Arndt von Aich is based on lost songbooks by Schöffer, I cannot follow their derived hypothesis that Schöffer 'developed his music font in conscious emulation of Oeglin', particularly the g-clefs, f-clefs and the custodes. The curly g-clef is also close to that of Petrucci, and the f-clef is a standard shape used by several other printers (see Appendix 1.3). The shape of the custos of all extant Schöffer editions is totally different from that of Oeglin (but again close to Petrucci's custos) and I wonder why Schöffer should have commissioned only a new custos after his two early, possibly lost song books were produced, since all other forms are stable. Also the tablature book from 1512 shows already the typical Schöffer/Petrucci custos. 
36 Oddly enough, in all three editions individual music fonts were used: in the Psalterium Spirense [1515] (vdm 729), the measurements of the notation are 14.0 / $9.5 \mathrm{~mm}$ (height of the staff / height of the virga); in the office De dulcissimo nomine Jesu, 1518 (vdm 972), the measurements are 11.5 / $6.0 \mathrm{~mm}$; and in the Responsoria Moguntina [1518] [vdm 261]) we measured 10.0 / $5.0 \mathrm{~mm}$.

37 For a discussion of the production of the 'Kampen Songbook', see Fallows, 'The Printed Songbook at Kampen'.

38 The process of producing music types is described in more detail in Krummel, 'Early German Partbook Type Faces', 80.

39 The one publication by Oeglin and the six publications by Schöffer the Younger are the only titles in this format in $v d m$. The measurements of the printed page vary between $98 \times 94 \mathrm{~mm}$ (vdm 27) and $125.5 \times 101.1 \mathrm{~mm}(\mathrm{vdm} \mathrm{111)}$. The number of staves on each page is usually four.

40 The first edition of Frosch's treatise is only recorded in a historical catalogue, which does not specify the format (see vdm 1534).

41 Staff heights in manuscripts vary between $7-9 \mathrm{~mm}$ in very small books and $27-28 \mathrm{~mm}$ in the largest ones (see Schmidt and Leitmeir, The Production and Reading of Music Sources, 16).

42 In Ruff's font, the longa was probably made by combining a breve and a stem during typesetting, since the stems are of various lengths, set on the right or left of the breve, pointing upwards or downwards. The note heads of these 'longae' are extended like the breves in Grimm's font.

43 An apparent shortening of the stems might also be caused by the covering of the underlaid text.

44 For a comparison of Grimm's and Ruff's fonts, see Tröster, 'Theobald Billican', 229-230, 232-233.

45 Nuremberg counts 75 editions, Wittenberg 36 and Augsburg 17. Strasbourg counts only three editions, all published around 1545 . The numbers of editions with mensural notated music until 1550 were extracted from $v d m$, accessed on 7 February 2019.

\section{References}

Bator, Angelika. 'Der Chorbuchdruck "Liber Selectarum Cantionum" (Augsburg 1520). Ein drucktechnischer Vergleich der Exemplare aus Augsburg, München und Stuttgart'. Musik in Bayern 67 (2004): 5-38.

Duggan, Mary K. Italian Music Incunabula: Printers and Type. Berkeley: University of California Press, 1992.

Fallows, David. 'The Printed Songbook at Kampen'. In NiveauNischeNimbus. Die Anfänge des Musikdrucks nördlich der Alpen, edited by Birgit Lodes. Wiener Forum für ältere Musikgeschichte 3. Tutzing: Schneider, 2010, 347-354.

Gaskell, Philip. A New Introduction to Bibliography. Oxford: Clarendon Press, 1972, 137-139.

German, Wilhelm. 'Der Buchhändler Johannes Rynmann von Öhringen 1460-1522', Württembergische Vierteljahrshefte für Landesgeschichte N.F. 23 (1914): 155-194.

Giselbrecht, Elisabeth, and Elizabeth Savage. 'Glittering Woodcuts and Movable Music: Decoding the Elaborate Printing Techniques, Purpose, and Patronage of the Liber Selectarum Cantionum'. In Senfl-Studien I, edited by Stefan Gasch, Birgit Lodes and Sonja Tröster. Wiener Forum für ältere Musikgeschichte 4. Tutzing: Schneider, 2012, 17-68.

Giselbrecht, Elisabeth, and Elizabeth Savage. 'Printing Music: Technical Challenges and Synthesis, 1450-1530'. In Early Music Printing in German-Speaking Lands, edited by Andrea Lindmayr-Brandl, Elisabeth Giselbrecht and Grantley McDonald. London and New York: Routledge, 2018, 84-99.

Grimm, Heinrich. 'Die Buchführer des deutschen Kulturbereichs und ihre Niederlassungsorte in der Zeitspanne 1490 bis um 1550'. Archiv für Geschichte des Buchwesens 7 (1967): col. 1153-1772.

Guillo, Laurent. "Made in Germany'. The Dissemination of Mensural German Music Types Outside the German-Speaking Area (and vice versa), up to 1650'. In Early Music Printing in German-Speaking Lands, edited by Andrea Lindmayr-Brandl, Elisabeth Giselbrecht and Grantley McDonald. London and New York: Routledge, 2018, 67-83.

Gustavson, Royston. 'Senfl in Print: The Einzeldrucke'. In Senfl-Studien 2, edited by Stefan Gasch and Sonja Tröster. Wiener Forum für ältere Musikgeschichte 7. Vienna: Hollitzer, 2013, 237-307.

Krummel, Donald W. 'Early German Partbook Type Faces'. Gutenberg Jahrbuch 60 (1985): 80-98. 
Künast, Hans-Jörg. 'Getruckt zu Augspurg'. Buchdruck und Buchhandel in Augsburg zwischen 1468 und 1555. Studia Augustana 8. Tübingen: Niemeyer, 1997.

Lindmayr-Brandl, Andrea. 'Magic Music in a Magic Square. Politics and Occultism in Ludwig Senfl's Riddle Canon "Salve Sancta Parens"'. Tijdschrift van de Vereniging voor Nederlandse Muziekgeschiedenis 60 (2010): 21-41.

Lindmayr-Brandl, Andrea. 'Peter Schöffer der Jüngere, das Erbe Gutenbergs und "die wahre Art des Druckens"'. In NiveauNischeNimbus. Die Anfänge des Musikdrucks nördlich der Alpen, edited by Birgit Lodes. Tutzing: Hans Schneider, 2010, 283-312.

Lodes, Birgit. 'An anderem Ort, auf andere Art: Petruccis und Mewes' Obrecht-Drucke'. Basler Jahrbuch für Historische Musikpraxis 25 (2001): 85-111.

Lodes, Birgit. 'Concentus, Melopoiae und Harmonie 1507: Zum Geburtsjahr des Typendrucks mehrstimmiger Musik nördlich der Alpen'. In NiveauNischeNimbus. Die Anfänge des Musikdrucks nördlich der Alpen, edited by Birgit Lodes. Wiener Forum für ältere Musikgeschichte 3. Tutzing: Hans Schneider, 2010, 33-66.

Lodes, Birgit. 'Gregor Mewes' “Concentus harmonici” und die letzten Messen Jacob Obrechts'. Unpubl. Habilitationsschrift, Universität München, 2002.

McDonald, Grantley. 'The Metrical Harmoniæ of Wolfgang Gräfinger and Ludwig Senfl in the Context of Humanism, Neoplatonism and Nicodemism'. In Senfl-Studien I, edited by Stefan Gasch, Birgit Lodes and Sonja Tröster. Wiener Forum für Ältere Musikgeschichte 4. Tutzing: Hans Schneider, 2012, 69-148.

McDonald, Grantley. 'Printing Hofhaimer: A Case Study'. Journal of the Alamire Foundation 7 (2015): 67-79.

McDonald, Grantley, and Sanna Raninen. 'The Songbooks of Peter Schöffer the Younger and Arnt von Aich: A Typographical Assessment'. In Senfl-Studien III, edited by Stefan Gasch and Sonja Tröster. Wiener Forum für ältere Musikgeschichte 9. Wien: Hollitzer, 2019, 29-54.

Picker, Martin. 'Liber Selectarum Cantionum (Augsburg: Grimm \& Wirsung, 1520), a Neglected Monument of Renaissance Music and Music Printing'. In Gestalt und Entstehung musikalischer Quellen im 15. und 16. Jahrhundert, edited by Martin Staehelin. Wiesbaden: Harrassowitz, 1998, 149-168.

Reske, Christoph. Die Buchdrucker des 16. und 17. Jahrhunderts im deutschen Sprachgebiet, aufder Grundlage des gleichnamigen Werkes von Josef Benzing. 2nd edition. Beiträge zum Buch- und Bibliothekswesen 51. Wiesbaden: Harrassowitz, 2015.

Röder, Thomas. 'Innovation and Misfortune. Augsburg Music Printing in the First Half of the 16th Century'. In Music Printing in Antwerp and Europe in the 16th Century, edited by Eugeen Schreurs and Henri Vanhulst. Yearbook of the Alamire Foundation 2 (1997): 465-478.

Schiefelbein, Torge. "Same Same but Different". Die erhaltenen Exemplare des Liber Selectarum Cantionum (Augsburg 1520)'. PhD dissertation, Universität Wien, 2016.

Schlagel, Stephanie P. 'The Liber Selectarum Cantionum and the "German Josquin Renaissance"'. The Journal of Musicology 19 (2002): 564-615.

Schmidt, Thomas, and Christian T. Leitmeir, eds. The Production and Reading of Music Sources. Miseen-page in Manuscripts and Printed Books Containing Polyphonic Music, 1480-1530. Épitome Musical. Turnhout: Brepols, 2018.

Seibicke, Wilfried. Vornamen, edited by the Gesellschaft für deutsche Sprache Wiesbaden. 2nd edition, Frankfurt am Main: Verlag für Standesamtwesen, 1991.

Stijnman, Ad, and Elizabeth Savage, eds. Printing Colour 1400-1700. History, Techniques, Functions and Receptions. Leiden: Brill, 2015.

Tröster, Sonja. 'Theobald Billican and Michael's Ode Settings in Print: Notes on an Exceptional Transmission'. In Early Music Printing in German-Speaking Lands, edited by Andrea Lindmayr-Brandl, Elisabeth Giselbrecht and Grantley McDonald. London and New York: Routledge, 2018, 225-244. 